\title{
THE LAW REVIEW MisSion: A STUdent Editor's Point of View
}

\section{LARISSA KATZ}

This paper focuses on the principles that ought to inform the choice of unsolicited articles for publication in the general issues ${ }^{\prime}$ of a student-run law review. Student editors are better able to operate the journal independently when they see their journal as an institution with specific commitments and aims. If students do not control the core aspects of a journal, its content, for example, the idea of a student-run law review, which is traditionally attached to the law school, is lost.

Student editors find it difficult to choose among articles submitted for publication. There are, I think, three ways such a choice can be made. The first is by resort to external criteria, arguably peripheral to the study of law itself, such as the needs of a defined audience. The Alberta Law Review, for example, receives generous funding ${ }^{2}$ from the Law Society of Alberta. In return, all members of the Law Society receive a copy of the Review. The editors implicitly assume that these practitioners form a homogeneous readership, with common needs and expectations. A more sophisticated understanding and definition of a review's audience could suffice to shape the content of that review. Another approach is to choose articles that in some way advance the law review's principled understanding of what is worthwhile legal scholarship. This would require a fairly coherent statement of the review's mission, one that is articulated in a way that allows hard choices to be made. The third approach, one which is often the default position for student-run law reviews, is simply the abdication, or more euphemistically the delegation, of editorial decision-making. It is immediately apparent that this approach is unsatisfactory, although it is prevalent among student-run reviews, such as the $A L R$.

There is a certain regularity to the work that is carried on at the Honourable W.A. Stevenson Alberta Law Review House, which now serves as much to establish the goals that structure our enterprise as to reflect those we have chosen. The apparent aim of any law review is the publication of meritorious works. The $A L R$, in adhering to a sustainable routine, efficiently produces a review of acceptablequality. Like most law reviews, it uses a double-blind, peer review system. The students' contribution is limited in this process: articles arrive unsolicited; articles editors cursorily assess the papers as worthy or

Former Law Clerk to Justice Gonthier of the Supreme Court of Canada and former Co-Editor-inChief of the Alberta Law Review. The author wishes to thank Professor Ziff for his comments on this paper and for our many inspirational discussions on the role of law reviews in legal academia.

' Throughout this discussion I use the experience of the Alberta Law Review (ALR) to furnish examples. The Review publishes four issues a year. One of these is the Petroleum Issue, in which the papers presented at the annual symposium of the Canadian Petroleum Foundation are collected. There is usually a "special issue" in each volume, in which solicited articles on a given topic are published. Recent special issues have focused on "restitution" and "judicial appointments." There are then two general issues that include solicited case comments. book reviews and, importantly, unsolicited articles of all kinds.

$2 \quad$ Of course, not all law reviews are as well-funded as the Alberta Law Review. Many rely on subscription fees and modest government subsidies. 
unworthy of being forwarded to peer reviewers and then decide to accept or reject based on the peer reviewer's often scanty report and conclusions. At the $A L R$, there is no internal reader's report, nor even a vote of the board of editors as a whole, as is the case at some Canadian journals.

There are of course many reasons for this mode of operation, none of which reflects badly on the students. A general law review receives papers on a variety of topics. Articles editors who are second and third year law students cannot possibly be prepared to assess each and every paper intelligently. Students' schedules, publication deadlines, and the fact that a submission to one law reviews is often being considered for publication by other major reviews in the country are constraints that prevent more than a summary assessment of a paper.

My point in sketching this picture, bleak as it might appear to some, is to emphasize that the student-run law review process can become mechanistic. The cottage industry begun by a few exceptionally keen students has become a full-scale factory, with an ample operating budget, ${ }^{3}$ support staff, faculty advisors, and a division of labour that is kept running by an (as yet non-unionized and still largely unpaid) force of students, year after year.

Publishing what peer reviewers deem publishable ought not to stand in for real decision-making by the students. Even though such a system works well enough, it sacrifices the idea that the journal is actually student-run. Student editors wind up doing the bidding of others, learning a little along the way, often by accident, but feeling still curiously outside the project.

The first approach I referred to above is to choose articles on the basis of the needs and expectations of the review's readership. If a law review begins by defining its intended audience - say the judiciary, Alberta practitioners or faculty members in Canadian law schools - it shapes ex ante, through an external limiting factor, what legal scholarship is worth advancing. This is an abdication of responsibility that is arguably less supportable than the form described above. It imagines, needs and envisions a type of homogeneity that is almost certainly inaccurate.

Having discounted the first two approaches, it should be evident where I am heading. The best approach, I think, is to shape the law review to reflect its commitment to a certain form of legal scholarship. The first step in this approach is to define what kind of scholarship the review is devoted to publishing and then to hope that those interested in this type of writing will respond by subscribing - or not!

I argue that a student-run law review should develop a mission statement that focuses on its commitment to a specific sort of legal scholarship. A peer review system is undeniably important, but it should perform a more limited function. Peer reviewers' reports should provide the editors with insight into the quality of the writing and research 
as well as a sense of the paper's originality and its contribution to the area. However, a reviewer is not responsible for the internal consistency and the direction of a law review.

Student editors, working from peer reviewers' reports, are responsible for the integrity of the journal. Familiar with the history of the review, its recent and upcoming publications, and most importantly its mission, they are in the position to say that a particular kind of paper on a particular topic meets the law review's peculiar criteria and thus should be published. This may seem trite, but it is something that is probably overlooked every day in the editorial processes of Canadian law reviews. Usually reviews are launched with a mission in mind; whether those stated objectives actually inform editorial boards thereafter is another matter altogether.

I have argued that the mission statement of a law review ought to be linked to its conception of scholarship. My own impressions on that subject, which are described below, are drawn from two recent experiences: one as an editor (of the Alberta Law Review); the other as a law clerk. By contrasting academic and judicial writing, I try to articulate a type of legal scholarship that a general, student-run law review, like the $A L R$, might find particularly worthy of attention. This sort of legal scholarship, as it turns out, has the least in common with most judicial writing, yet at the same time it valuably and directly contributes to the development of the law. A law review that aims at advancing this sort of work takes on some of the importance of the scholarship it publishes.

It has been argued that the relationship of the academy to the judiciary is symbiotic. ${ }^{4}$ The academy, on this account, serves only to nourish and to advance the work of the judiciary. In my view this is not true of all academic work, although it accurately describes one useful type that critiques and develops particular aspects of the law. This scholarship aims to reconcile apparent inconsistencies in the case law, to identify weakness in judicial reasoning on certain narrow points, and to advance the best version of a particular doctrine of law, which can then be judicially grafted onto its existing but imperfect form. This sort of enterprise is bound to the cases, to specific fact scenarios, whether concocted or real, and to the idea that incremental change in the law is best.

Scholars engaged in that type of project share some of the judiciary's concerns and assumptions about the law. ${ }^{5}$ The judiciary and these academics have in common certain operating premises about the legitimacy of the larger legal order within which the developments in the case law take place. For instance, one would not expect that an article on recent developments in oil and gas law would contain a challenge to the idea of property in Canadian society. Likewise, judges might peck away at the edges of a juridical concept such as property, but no court is likely to declare, with Prudhon, that "property is theft." Judges do not look back at their decisions as behavioural evidence of the judicial

$4 \quad$ D. Barnhizer, "Prophets, Priests, and Power Blockers: Three fundamental roles of judges and legal scholars in America" (1988) 50 Univ. Pittsburgh L. Rev. 127.

I leave aside a discussion of common educational foundations, or career paths. I am interested here only in comparing two crafts. 
institution which invites social commentary. They see their judgments as a concatenation of precedent and reason. So too does this breed of academic. ${ }^{6}$

Less significant is the similarity evident in the form and style between such academic writing and most judicial writing. Canadian Courts, in particular the Supreme Court of Canada, adopt a deliberately scholarly model (a style introduced at the Supreme Court level by Chief Justice Dickson) that exhaustively sets out the facts, the decisions below, the existing law in the area, and then reasons to a conclusion. The lengthy judgments that are produced at the Supreme Court are called, at least internally, "reasons" rather than "opinions," or "judgments" even, as they are in the United States. It is in vogue, as Mr. Allen notes in his book, Law in the Making, for a judge's decision to be "given the form of a structure of logic, in which he may use any material which he considers ad rem."7 Some academic writing is similarly constructed. The "black letter" academic often mimics the judiciary's "academic" posture.

If the proper scope of academic endeavour were limited to this sort of immersion in the nuts and bolts of case law, academics would not be contributing directly to the development of the law. In restricting herself to shadowing judicial decision-making, the best an academic can do is to adopt the basic building blocks handed down by the judges and arrange them differently. A court's decision does not masquerade as reasons derived from first principles. Academics, in arguing how a case ought to have been decided, cannot claim that their conclusions are true, nor can they assert a court's conclusion is false. The most that can be said is that in the opinion of the academic, its arrangement of accepted principles within the confines of precedent is better than that found on the books. The argument is thus reducible to a judgment call, and, in such a contest, the position of the judge, who is appointed because we repose faith in his or her good judgment and practical wisdom, must always win.

Although it is clear that this sort of academic writing is closely related to judicial writing, the two are critically distinct: an academic's conclusion cannot amount to a declaration of law, as does a similar conclusion by a judge. Absent the authoritative status that judicial conclusions have, an academic conclusion that asserts a better version of a particular doctrine does not directly change the law. At best, where a judge adopts an academic's view as her own, the academic in question influences judicial (direct) development of the law.

In our legal system, where fairness in the process itself rather than justice in the result is paramount, great care has been taken to prevent such academic opinion from generating judicial conclusions. That, perhaps, is why Chief Justice Beverley McLachlin issued a policy statement advising law professors across Canada not to send manuscripts or articles Judging, Or,'Don't Let the Bastaraches Grind You Down,"' (2001) 39 Alta. L. Rev. 657.

C.K. Allen, Law in the Making, 7th ed. (Oxford: Clarendon Press, 1964) at 286 [emphasis in original]. 
to the Supreme Court. ${ }^{8}$ Chief Justice Rinfret, in Reference Re Validity of the Wartime Leasehold Regulations, ${ }^{9}$ would not allow counsel to cite an article from the Canadian Bar Review on the grounds that it was "not an authority in this Court."10 This sort of academic work has been pegged as a "secondary source"; that term captures the popular understanding of the academic's role.

There is, however, another type of legal scholarship that in its way contributes directly to the development of the law and thus might even be considered a "primary source." In the context of such academic work, I use the term "development" to refer to the organizing of existing and discrete legal rules into a coherent structure that guides understanding and application of the law. An example is the collection of papers edited by Peter Birks entitled The Classification of Obligations." Works such as this posit ways to articulate a particular doctrine so as to resolve problematic reasoning in the law; they cover a greater range of fact scenarios than the cases provide, and they seek to ensure greater consistency. They are also innovative in other ways, prescribing legal rules or principles designed to promote the best and most coherent version of an area of law.

The inherent limits in the judiciary's ability to develop the law create the need and the room for this sort of work. In TWA v. Franklin Mint, Justice Stevens noted (in dissent): "the limits of ... judicial authority and ... ability to develop the law should always be respected." 12 In other words, in the development of new law, the legislator contributes in ways that the judiciary is not able to in the proper performance of its task. There are always matters of pure policy, for example, that determine the direction of the law and which it is the responsibility of our elected representatives to decide. Likewise, there are some matters integral to the law that are better considered the province of the academy as they simply cannot be tackled by the judiciary.

The core contribution of the academic to the development of the law is found in the activity that she performs best. It is hardly contentious, as I indicated above, that the judiciary is constrained in a way that the legal academic is not. A single case that happens to come before the court is simply not the ideal vehicle within which to develop whole areas of the law. The Supreme Court, because it has greater control over what it hears and when, can perhaps be the most strategic of all Canadian courts in its choice of cases. Even so, the Court cannot undertake the large-scale re-examination of legal doctrine in the manner of academic writing. Further, judges might not even want to take on such a project, perhaps finding it at odds with the conservative ideal of judicial restraint. As Lord Goff, in musing on the work to be done by a judge, put it:

It is essential that, in seeking to develop the law, the judges should so far as possible operate within the confines of the principle of gradualism. They should consciously allow themselves to be influenced by

See further B. Ziff. "The Canadian Law Review Experience: Introduction to the Symposium" (2001) 39 Alta. L. Rev. 611.

[1950] S.C.R. 124.

G.V.V. Nicholls "Legal Periodicats and the Supreme Court of Canada" (1950) 28 Can. Bar Rev. 422 at 422. See also J.E. Côté, "Far-Cited" (2001) 39 Alta. L. Rev. 640 at 640.

(Oxford: Clarendon Press, 1997).

52 U.S.L.W. 4445 (17 April 1984) at 4455 (n. 12). 
the facts of the cases which they have to decide and allow their intuitions as lawyers to influence them in adapting or qualifying existing legal principle to achieve their just result. ${ }^{13}$

Although scholars seem content to adopt the ethos of gradualism, a legal academic is uniquely free to think and write about the law with a degree of detachment from particular facts and the particular way in which the parties bringing a case for decision see fit to frame their case. A legal academic is uniquely suited to provide structure and coherence to the law. She is in the position to seek out its very foundations.

What does this mean for a law review in its effort to define its raison d'être? In my view, when choosing among articles, editors should appreciate that scholarship is the only means through which to map out a principled, theoretical structure to the law. Such an enterprise should be given every ounce of support that a law review can offer. In other words, where such work comes across the desk of an editor, it should be given preference. More generally, law reviews should seek out the types of critique and analysis that cannot be undertaken by the courts.

I do not deny the importance of encouraging the free submission of articles and of avoiding the creation of a "by invitation only" review. If law reviews were to dictate what projects ought to be pursued, our academic community's diversity and dynamism would suffer. Still, the law review, in supporting academic freedom, need not be directionless or maintain an element of arbitrariness in what publishable papers actually make it into print. Student editors ought to be charged with developing a mission statement that reflects a principled commitment to certain forms of legal scholarship, and they ought to use such a mission statement for the selection of articles. In so doing, student editors will be participating meaningfully in a genuinely "student-run" review. 